\title{
Grazing Increases Soil Warming in Headwater Wetlands: Importance to Land Managers and Water Users
}

\author{
D. Terrance Booth,${ }^{1 *}$ John C. Likins, ${ }^{2}$ Samuel E. Cox,${ }^{3}$ Jay B. Norton,,${ }^{4}$ and \\ Richard C. Anderson-Sprecher ${ }^{4}$
}

${ }^{1} U S D A-A R S$, Cheyenne, Wyoming, USA $;{ }^{2} U S D I-B L M$, Lander, Wyoming, USA $;{ }^{3} U S D I-B L M$, Cheyenne, Wyoming, USA; ${ }^{4}$ University of Wyoming, Laramie, Wyoming, USA

\begin{abstract}
The earth's mountains continue to lose water. Glaciers are melting and mountain snow/rain balance tilts increasingly liquescent. Water is running off sooner-sometimes overfilling reservoirs, causing flooding, and setting the stage for late-season shortages. One adaptive strategy is to recover and enhance water-storage capacities of headwater riparian systems. Grazing, a common use of headwater lands, affects both soils and vegetation. To better understand how grazing might affect water storage and other ecosystem services of high elevation riparian wetlands, we measured soil-profile temperatures, soil organic matter (SOM), and phytomass at six sites in the upper Sweetwater River sub-basin of Wyoming, USA, where fence lines allowed us to contrast grazing management. We found grazed wetlands consistently had warmer soils than fenced wetlands. We found added
\end{abstract}

Received 16 January 2021; accepted 25 August 2021; published online 29 September 2021

Author contributions: Conceived of or designed study: DTB JCL JBN, Performed research: DTB JCL SEC JBN, Analyzed Data: DTB SEC JBN RCA, Wrote paper: DTB JCL SEC JBN.

*Corresponding author; e-mail: Terry_Booth@outlook.com evidence that SOM is important in both soil temperature control and water-storage potential of wetlands. We review evidence that warmer soil temperatures and drying cause loss of SOM with the implied concomitant $\mathrm{C}$ losses through erosion and emissions. We recommend land managers of temperate-climate headwater systems consider the need to end growing seasons with full stands of riparian vegetation to reduce soil warming and to build organic matter-particularly on lands where municipalities and other downstream water users are seeking long-term increases in water yields and less flooding.

Key words: climate change; grazing management; water conservation; riparian water storage; soil organic matter; soil profile temperatures; subsurface ice; soil thaw.

\section{HighLIGHTS}

- Grazed wetlands had greater temperature variability than fenced wetlands

- Grazed wetlands had warmer soil profiles, and earlier thaws, than fenced wetlands

- Fenced wetlands had more soil-temperature modulating soil organic matter 


\section{INTRODUCTION}

Our warming earth is losing mountain-stored water. Between 1966 and 2006 the total surface area of 44 glaciers in the Wind River Mountains of Wyoming, U.S.A, decreased 38\% (Cheesbrough and others 2009; Nayak and others 2010; Thompson and others 2011). Farinotti and others (2015) reported a similar $27 \pm 15 \%$ loss of total glacier mass from 1961 to 2012 in the Tien Shan Mountains of central Asia. Those measurements were cross validated with satellite gravimetry (GRACE), laser altimetry, and glaciological modeling. These findings support other reports of glacier losses by Howat and Eddy (2011) and Marzeion and others (2014). Farinotti and others referred to the Tien Shan Mountains as "water towers" to emphasize downstream human dependence on this water for domestic use and food production in mountainwatered arid-lands around the world.

The loss of mountain-stored water is well documented; compensating adaptive management is less developed. Holding liquid water in headwater systems can be accomplished through infrastructure such as wetlands or dams (Cosgrove and Loucks 2015). Dams, however, often come with significant cost-including unaccounted costs as reported by the World Commission on Dams (Berkamp and others 2000); the unaccounted costs often including displacement of people, and losses of farmland, wildlife habitat, and wetlands with their associated ecosystem services.

Numerous studies indicate livestock grazing often damages riparian systems. Elmore and Beschta (1987) concluded, "...when we look at all the factors that can and do influence the present condition of riparian areas in the (U.S.) West, livestock grazing is unquestionably a significant factor." Case studies document increases in riparian vegetation and water table with decreases in channel incision, bank sloughing, and headcutting after complete or partial exclusion of livestock without any other mitigative action (Elmore and Beschta 1987; Swanson and others 1987; Bezanson and Hughes 1989; Odion and others 1990; Nagle and Clifton 2003; Beschta and others 2012; Booth and others 2012; Warren and Jones 2012; Batchelor and others 2015). A grazing effect that has been less studied is the decreased carbon concentrations in grazed wetlands. Moomas and others (2018) commented that "Wetlands sequester some of the largest stores of carbon on the planet, but when disturbed or warmed, they release the three major heat-trapping greenhouse gases, carbon dioxide $\left(\mathrm{CO}_{2}\right)$, methane $\left(\mathrm{CH}_{4}\right)$ and nitrous oxide $\left(\mathrm{N}_{2} \mathrm{O}\right)$."
Additionally, grazing-related soil-carbon reductions reduce soil water storage. Organic matter increases will boost soil water-holding capacities by 3 to more than $25 \%$ depending on soil characteristics and the formation of peat layers (Hudson 1994; Biglow and others 2004; Nusier 2004). Organicrich soils have greater porosity, greater hydraulic conductivity, and wetter soil columns, than carbon poor soils (Lawrence and Slater 2008). Thus, large soil carbon losses are likely to result in large reductions in soil-water-storage capacity. We need more knowledge of why and how grazing influences water storage beyond the question of visible erosion. We also need to ask if land managers and national regulators are effectively monitoring the most important indicators? Optimizing riparian headwater storage requires an improved understanding of surface and subsurface grazing effects on the stringer meadows and small wetlands of high-elevation headwater systems.

Ice Slough (Figure la) is a noted feature of central Wyoming. A highway marker informs that the slough is a tributary of the Sweetwater River where early travelers recorded finding 15 -cm-thick ice layers as late as July by digging $30-60 \mathrm{~cm}$ below the surface (Clayton 1848; Delano 1854). The marker concludes that "due to a number of factors" now ... "little (subsurface) ice forms here in the winter." Consequently, two of us (Booth and Likins) collected core samples in May 2010, from another Sweetwater River tributary-the PB Creek wetland (described below). Three samples contained layers of clear ice, $7.6 \mathrm{~cm}$ thick, approximately $25 \mathrm{~cm}$ below the surface. These samples were all inside a private pasture where grazing was then limited to 15-20 days per year. Three similar samples outside the enclosure and roughly $100 \mathrm{~m}$ downstream on land that historically had 180-day annual grazing permits, had no ice. There was no surface snow or ice at either sampling location. Thus, early observations and more recent data from the upper Sweetwater basin, suggest that over time and location, a valuable water-storing phenomenon may have been lost from area wetlands.

We believe that one important driver of warmer soil temperatures, as represented by the contrast of Ice Slough today with historical accounts and with our PB Creek observations, is grazing that removes plant residues. Vegetation acts as an insulation layer that influences soil temperature (Gonzalez and Smith 2020), a salient consideration in this study. A series of long-term grazing exclosures situated in herbaceous riparian wetlands of our study area creates an excellent opportunity to test this hypothesis. Given the ubiquity of grazing as a 




Figure 1. Wyoming study site locations (a), illustration of fence line plots (b), temperature sensors in housing being installed in core hole $(\mathbf{c})$, and temperature sensor housing after installation $(\mathbf{d})$.

headwaters land use throughout the world, this is a foundational question for the conservation and restoration of headwater wetlands anywhere on earth.

\section{MethoDs}

\section{Study Sites}

The Wind River Mountain Range is part of the Rocky Mountains of western North America's cordillera. At the Range's southern end, the Continental Divide splits around Great Divide Basin in Wyoming, causing the Sweetwater River, which parallels the east side of the hydrologic divide near the split, to bend around the southern end of the Range and drain to the Atlantic (Figure la). The wetlands we sampled lie in the upper portion of the Sweetwater River sub-basin, at approximately 2200-m elevation in the sagebrush-dominated (Artemisia tridentata Nutt. ssp. wyomingensis Beetle and Young; Artemisia tridentata Nutt. ssp. vaseyana (Rydb.) Beetle) cold-desert uplands where the annual precipitation is $30-40 \mathrm{~cm}$, received mostly as snow that blows off the uplands into draws and drainages or lee-side slopes and escarpments where it feeds the area's riparian systems (see Hunt 2006). The riparian vegetation is dominated by Nebraska sedge (Carex nebrascensis Dewey). Livestock grazing began here in the 1840s and continues today. This is mostly public land administered by the U.S. Department of Interior, Bureau of Land Management (BLM). 
We examined grazing effects at fence lines of six wetlands (Figure la, Table 1). Five sites have domestic livestock exclosures established by the BLM to monitor vegetation or protect a spring source. While livestock breaches of these exclosures are known, the long-term goal of a meaningful reduction in grazing was realized. The remaining site (PB Creek) is a fenced private pasture surrounded by BLM administered land (an inholding). It was grazed less than 20 days annually for more than 50 years and has $\sim 50 \%$ soil organic matter (SOM, Table 2) in the A horizon. The pasture has been grazed more intensely since about 2014. Our study sites were selected opportunistically (nonrandom), being wetlands in the region accessible to us where long-term grazing exclosures existed (Williams and Brown 2019). They provide evidence of landscape-scale ecological function that is broadly representative of temperate, grazed semiarid riparian wetlands.

Soils of the study area are mapped as Mollisols, with Ustic Argicryolls and Ustic Haplocryolls on uplands and Typic Cryaquolls in swales and riparian meadows (Soil Survey Staff, 2021). Kasten (2018) described soil profiles at the wettest landscape position associated with each exclosure except PB Creek, identifying histisols with deep peat and mucky peat horizons at the Weasel Spring and Long Creek sites (classified as Typic Cryofibrists), with thinner histic horizons at most others (classified as Typic, Cumulic, and Histic Cryaquolls). The drier Atlantic City site was classified as Inceptisols (Aquic Haplocryepts). Mineral soil textures were loams and sandy loams.

Soil profiles sampled for this study using a $2-\mathrm{cm}$ probe near the center location of each temperature sensor transect (Figure $1 \mathrm{~b}$; described below) indicate that all the surface horizons have elevated soil organic carbon contents (SOC; quantified by combustion analysis) indicative of wetlands ( $\geq 5 \%$
SOC) with organic horizons ( $\geq 15 \%$ SOC) $16-22$ $\mathrm{cm}$ thick at the PB site and $2-4-\mathrm{cm}$ thick at the Gilespie site.

Public land around the six sites had mostly season-long (180-day) grazing permits for the approximately four decades since free-roaming cattle replaced herded sheep on the allotments. Beginning with the 2014 grazing season, permitted livestock use in the allotment containing PB Creek, Wagon Tire Spring, and Weasel Spring (Table 1), was reduced $45 \%$ (20\% in numbers and $33 \%$ in season length; Stacie Thompson, BLM Office, Lander, WY, personal communication 15 February 2019). Also, in 2014, an ordered herding requirement to reduce grazing on riparian areas was implemented (Administrative record on file at Lander BLM Field Office).

\section{Sampling Plan}

At each of the study-site fence lines, we established six $1-\mathrm{m}^{2}$ plots, three on each side of the exclosure fence (inside and outside; Figure lb). To avoid location bias for the replicating plots, we identified more than three outside-plot locations and used random assignments (dice) to determine the final locations. Inside plots were placed at mirrored locations on the other side of the fence. Transects for locating plots ran parallel with the fence (offset $20 \mathrm{~m}$ for temperature and vegetation plots and $10 \mathrm{~m}$ for the SOM transect) and perpendicular to the channel, beginning and ending at the visible riparian-upland vegetation boundary (Wyoming big sagebrush) or as allowed by exclosure size (Figure lb).

\section{Soil Temperature}

Miniature temperature data-loggers (Maxim iButton, Fondriest Environmental Inc, Fairborn, $\mathrm{OH}$, US) were used to record temperatures at 2 -h

Table 1. Upper Sweetwater Watershed Study-site Descriptions Including Elevation, Geographical Location, the Proportion of the Exclosure which is Riparian Habitat (Riparian), the Size of the Exclosure (Total), and the Year the Exclosure was Installed

\begin{tabular}{|c|c|c|c|c|c|c|}
\hline \multirow[t]{2}{*}{ Wetland } & \multirow[t]{2}{*}{ Elev. (m) } & \multirow{2}{*}{\multicolumn{2}{|c|}{$\begin{array}{l}\text { Location } \\
\text { (Lat./Long.) }\end{array}$}} & \multicolumn{2}{|l|}{ Area (ha) } & \multirow[t]{2}{*}{ Year enclosed } \\
\hline & & & & Riparian & Total & \\
\hline Atlantic City & 2244 & $42.338^{\circ}$ & $-108.652^{\circ}$ & 0.3 & 0.4 & Fall 1982 \\
\hline Gilespie Creek & 2267 & $42.463^{\circ}$ & -108.516 & 0.3 & 0.3 & Fall 1982 \\
\hline Long Creek & 2095 & $42.697^{\circ}$ & $-108.001^{\circ}$ & 0.4 & 0.4 & Fall 1982 \\
\hline PB Creek & 2187 & $42.338^{\circ}$ & $-108.422^{\circ}$ & 6.9 & 41.7 & $\sim 1953$ \\
\hline Wagon Tire Spring & 2248 & $42.381^{\circ}$ & $-108.442^{\circ}$ & 0.6 & 6.1 & Sept. 2004 \\
\hline Weasel Spring & 2243 & $42.382^{\circ}$ & $-108.366^{\circ}$ & 2.4 & 24.3 & Sept. 2000 \\
\hline
\end{tabular}


Table 2. Phytomass $(n=3)$ and Soil Organic Matter (SOM; $n=$ variable) Inside and Outside Grazing Exclosures at Six Riparian Meadows

\begin{tabular}{|c|c|c|c|c|c|}
\hline \multirow[t]{2}{*}{ Wetland } & \multicolumn{2}{|c|}{ Dry Wt $(\mathrm{g}) \pm \mathrm{SD}$} & \multicolumn{2}{|c|}{$\operatorname{SOM}(\%) \pm \mathrm{SD},(\mathrm{N})$, and In vs Out $P$ value } & \multirow[b]{2}{*}{$P$} \\
\hline & Inside & Outside & Inside & Outside & \\
\hline Atlantic City & $11.3 \pm 7.1$ & $3.2 \pm 0.4$ & - & - & - \\
\hline Gilespie Creek & $5.7 \pm 2.6$ & $4.3 \pm 1.2$ & - & - & - \\
\hline Long Creek & $16.3 \pm 3.7$ & $3.6 \pm 0.2$ & - & - & - \\
\hline PB Creek & $8.4 \pm 2.8$ & $7.3 \pm 3.7$ & $52.7 \pm 12.6(21)$ & $36.2 \pm 16.6(24)$ & 0.012 \\
\hline Wagon Tire Spring & $7.1 \pm 2.7$ & $3.9 \pm 1.0$ & $20.4 \pm 6.5(15)$ & $13.6 \pm 4.6(15)$ & $<0.001$ \\
\hline Weasel Spring & $12 \pm 4.6$ & $7.6 \pm 1.4$ & $17.4 \pm 3.6(36)$ & $14.5 \pm 2.4(24)$ & $<0.001$ \\
\hline Mean & $10.1 \pm 1.7$ & $5.0 \pm 1.3$ & $30.2 \pm 20.0$ & $21.7 \pm 12.4$ & \\
\hline
\end{tabular}

For phytomass AOV see Table 3.

Phytomass dry weight was $\sim 2 X$ greater inside the exclosures relative to the grazed area $(P<0.001, n=3 ;$ Tables 2 and 3$)$. SOM samples were acquired at a distance of $10 \mathrm{~m}$ inside (upstream) and outside (downstream) of the exclosure fence. The SOM for PB Creek Outside was influenced by an inability to systemically sample that transect and might be reasonably estimated as $<20 \%$ if the unsampled, gravelly, low SOM, interspaces had been included in the mean. SOM means inside the exclosures were significantly greater than outside at Bonferonni-corrected $\alpha=0.0167$, that is, alpha at $95 \%$ confidence level.

intervals, $\pm 1{ }^{\circ} \mathrm{C}$, at four soil depths $(3,20,40$, and $60 \mathrm{~cm}$ ), in 36 plot locations among the six wetlands from February to August of 2016 and 2017. Miniature temperature data-loggers have been used in similar applications (Pickering and Green 2009; Juliussen and others 2010; Scherrer and Körner 2011). To facilitate removal and replacement for downloading data, loggers were set in 76$\mathrm{cm}$ long, 3.8-cm inside-diameter PVC pipe housings with 25.4-mm diameter holes drilled into one side for the waterproof-capsule enclosed data-loggers (Figure 1c). Housings were filled with insulation to stabilize and insulate the data-logger capsules from each other. A core hole at each site was used to place data-logger housings into the soil profile. Fitted PVC caps were glued on the tops of the housings and drilled horizontally to allow a steel rod to be used in pulling the housings from the ground; these openings were taped closed when not in use. We used a 15.2-cm length of $10-\mathrm{cm}$ diameter PVC pipe to form a protective enclosure on the surface around logger-housing tops. These were attached to a length of rebar driven into the ground (Figure ld). Logger calibration was confirmed using an ice-bath before placement. As a test of our method and equipment, loggers and housings were placed in the ground spring/summer 2015, removed in August 2015, and successful temperature logging was confirmed. Loggers were then programed to record February 15 to August 9, 2016, and data-loggers and housings were placed in the ground in October 2015. Housings were removed August 2016, to download data and confirm operation. All data-loggers and housings were replaced in the ground in October 2016, and recorded temperature for a second year for the same inter- val. Housings were removed August 2017, and data downloaded.

To remove daily variation, observations were aggregated as daily means for the (usually) 173 full days of recorded soil temperatures. A typical pattern over time consists of stable or nearly stable temperatures near $0{ }^{\circ} \mathrm{C}$ until thaw, after which daily means approximate a segment of a sine wave of period one year. (Note: There is a sequence of thaw/freeze/thaw-that is, daytime thawing, nighttime freezing, but also alternating cold and warm spring weather patterns-so there is not an unambiguous thaw date. We calculated 7-day rolling temperature means to document soil thaw.) Parameter estimates for this sine wave were obtained with uncertainty, accounting for autoregressive-moving-average (ARMA) autocorrelated errors (ARMA models address temporal dependencies, allowing for correct statistical inference when data violate standard independence assumptions; Abaurrea and others 2011). These parameters were used to calculate estimates and associated standard errors (via the delta method which estimates standard errors under nonlinear transformations (Shumway and others 1989)) for two biologically meaningful measures of the fitted curves: (1) the annual maximum mean daily temperature $(\max T)$, and $(2)$ the rate of temperature increase following thaw. A modest number of outliers were present in the data and not removed. Given outliers, we measured $\max T$ using the peak of the fitted sine wave. Similarly, rate of temperature increase following thaw is a property of the estimated sine wave.

Temperature data are separated by site and depth and grazing $(6 \times 4 \times 2=48$ "treatments" $)$ for 
both years of the study. For each of these treatments we looked at two summary measures (both based on daily mean temperature): maximum of daily mean temperatures and rate of thaw at the scale of change in daily mean temperature per day.

Responses described above are fit to linear models with variables site, depth, and grazing. All interactions were considered, as were different ways to model the depth predictor (linear, quadratic, or 4-level factor variable). Final models were selected using Akaike information criterion (AIC, a widely used model selection criterion that assesses relative model performance by formally balancing goodness-of-fit against model complexity (Aho and others 2014)) and corroborated using likelihood ratio tests.

\section{Phytomass}

In September 2016, between years 1 and 2 of soil temperature data collection, we measured aboveground phytomass to test the effect of grazing on residual vegetation in the wetland going into winter. At each of the six meadows, we placed a 1-m diameter circular plot frame centered on each of the installed soil temperature sensor housings (three inside the exclosure and three outside). At each circular plot, we placed three square $10-\mathrm{cm}^{2}$ quadrats just outside the circular frame at premarked, equidistant locations $\left(0^{\circ}, 120^{\circ}, 240^{\circ}\right)$. We clipped and bagged all vegetation within each 10 $\mathrm{cm}^{2}$-quadrat, for a total of three observations/ sample, and three samples/treatment. All bags were dried at $80^{\circ} \mathrm{C}$ for $14 \mathrm{~d}$, and then weighed. We averaged the three observation dry weights for each sample. We used R v2.14.0 for statistical analysis. The data residuals showed unequal variance, so we log-transformed the data before running a two-way ANOVA with variables treatment and site.

\section{Water-Storage Capacity and Soil Organic Matter (SOM)}

A positive feedback loop exists between SOM accumulation and water storage in all ecosystems and in all soil-texture groups; however, SOM accumulation is normally greater in wetland soils due to the inhibition of decomposition in saturated soils (Hogan and others 2004, citing Mitsch and Gosselink 2000). As SOM increases from 0.5 to $3 \%$, the available water holding capacity of the soil more than doubles (Hudson 1994). Where 5, 10, 15 , or $20 \%$ peatmoss was added to soils, water holding capacity increased significantly and could double, or more, depending on the soil and the dry bulk density of the mixture (Biglow and others 2004; Nusier 2004). Herbaceous-plant organic matter (peat) with bulk densities of $0.14-0.24 \mathrm{~g} \mathrm{cc}^{-1}$ holds $80-90 \%$ water, and dried Sphagnum spp. at $0.02 \mathrm{~g} \mathrm{cc}^{-1}$ holds 95 to nearly $100 \%$ by volume at saturation (Boeleter 1964). Live Sphagnaceae can hold up to 25 times their dry weight in water (McQueen and Andrus 2007). Thus, measures of SOM concentration give an indication of soil waterstorage capacity.

SOM concentration was sampled (Booth and Likins, June 2011, unpublished) to 25-cm depth at 3 sites: PB Creek, Weasel Spring, and Wagon Tire Spring, using cross-riparian-area transects that were $10 \mathrm{~m}$ inside and outside the fence and upstream and downstream from the fence, respectively. Transect lengths varied but started and ended at the wet zone in the ribbon community of rush (Juncus) along each bank. Samples were obtained at 2-m intervals along the transects using a $7.2-\mathrm{cm}$ inside diameter soil sampling tube (Giddings Machine Company, Fort Collins, CO, US) with a serrated cutting bit. The tube was powered into and out of the soil with a 2-man power posthole auger (Groundhog, Model $\mathrm{C} 715 \mathrm{H}$ ) using a custom-built adapter. Each $25-\mathrm{cm}$ soil core was placed in a polyethylene bag and stored away from direct sunlight. Sample numbers ranged from 15 to 36 samples per transect. At the outside transect on PB Creek, gravel layers prevented sample collection at points located between, or on the edge of the large erosion pedestals (hummocks). To avoid gravel layers, we sampled hummock centers and acknowledge sampling bias for this transect both with respect to representation of low SOM interspaces and due to transect placement within an area (only $10 \mathrm{~m}$ below fence) influenced by high upstream (inside) SOM concentrations. The entire $25-\mathrm{cm}$ core of the soil samples was oven dried to a constant weight $\left(24-48 \mathrm{~h}\right.$ at $\left.100 \pm 5^{\circ} \mathrm{C}\right)$. Roots and other large organic material were removed, saved aside, and mill-ground. The soil fraction was ground using mortar and pestle and then made to pass through a 2-mm sieve. Both fractions were then recombined, made to pass through a 500micron sieve, and thoroughly mixed. Three subsamples $(\sim 10-g)$ were taken from each sample; the sample was remixed before each subsample was taken so that SOM values represent a mix of the entire $25-\mathrm{cm}$ core sample. Thus, this survey used multiple observations within samples and within and among study sites. SOM was determined using loss-on-ignition (Nelson and Sommers 1996). Because of the large difference in SOM concentration 
between PB and the other two sites, means for SOM by grazing treatment for each of the three sites were compared (inside vs outside) using $t$-tests with Bonferroni correction.

\section{RESUlts}

\section{Soil Temperature}

Temperature differences between years were not consequential in terms of $\max T$. Pairwise differences in $\max T$ (matched by location within site) between 2016 and 2017 averaged less than a tenth of a degree $\left(0.0835{ }^{\circ} \mathrm{C}\right)$, not a significant difference $(p=0.211)$. Yet, a pairwise comparison of log thaw rate (matched by location within site) between 2016 and 2017 showed that 2016's average thaw rate was a significant $21.7 \%$ faster $(p<0.001)$; however, 2016 thaw dates averaged more than a week later $(7.775$ days; $p<0.001)$. These two differences effectively canceled each other out in terms of temperature stress, and maxT, making the soil temperatures from the 2 years equivalent. (Note: We infer that later thaw is consistent with rapid thaw rates-the longer soils remain frozen as spring advances, the faster their thaw rate due to warmer, longer days later in the spring. Naturally, interannual temperature variations are expected to have some influence on thaw rates and dates.) With respect to grazing, our two years of data do not have consequential differences except as dis-
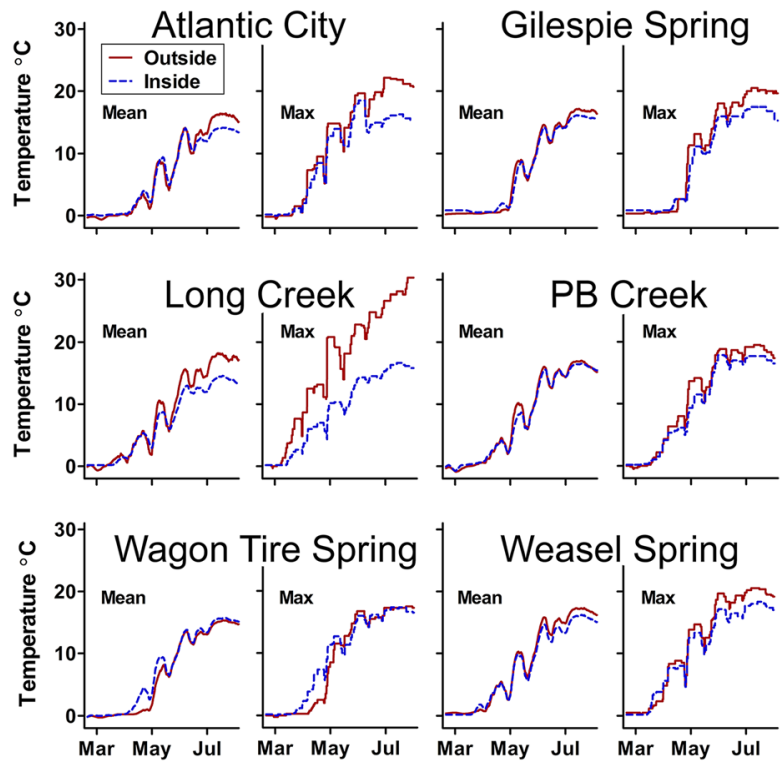

Figure 2. Seven-day rolling mean and max temperature for the 3 -cm depth by site, averaged across plots $(N=3)$ inside (ungrazed/blue) or outside (grazed/red) grazing exclosures. cussed below; therefore, we have streamlined our report by using only 2017 data in figures illustrating grazing effects.

Temperatures were consistently higher and less stable in grazed plots (Figures 2, 3, 4, 5). Outside and inside soil temperatures at PB Creek differed only slightly at $3 \mathrm{~cm}$ but differed by much more at $40 \mathrm{~cm}$ (Figures 2 and 3). Mean maximum soil temperature $(\max T)$ was higher on grazed plots at all sites, at all depths (Figure 6); though, high variation rendered many differences not statistically significant, the overall difference between grazed and ungrazed is highly significant $(p<0.001$ based on the assumed stochastic structure of the model). Over a week's time, maximum temperatures at $3 \mathrm{~cm}$ were as high as $30^{\circ} \mathrm{C}$ in grazed sites (compared to $18{ }^{\circ} \mathrm{C}$ in ungrazed sites; Figure 2). At $40 \mathrm{~cm}$, maximum temperatures were lower and more consistent, (typically about $15{ }^{\circ} \mathrm{C}$ with differences between grazed and ungrazed maxima about $0.5^{\circ} \mathrm{C}$ ).

Variation between and within wetlands was high; notwithstanding that variation, the differences between soil temperatures for grazed versus ungrazed plots were reasonably consistent (Figures $2,3,4,5)$. As expected, $\max T$ decreased linearly with depth in a similar manner at all locations. The rate of temperature increase after thaw was faster in grazed plots at five of six sites (Figure 7). Thaw rates slowed with depth. We tested whether the slopes of the linear changes with
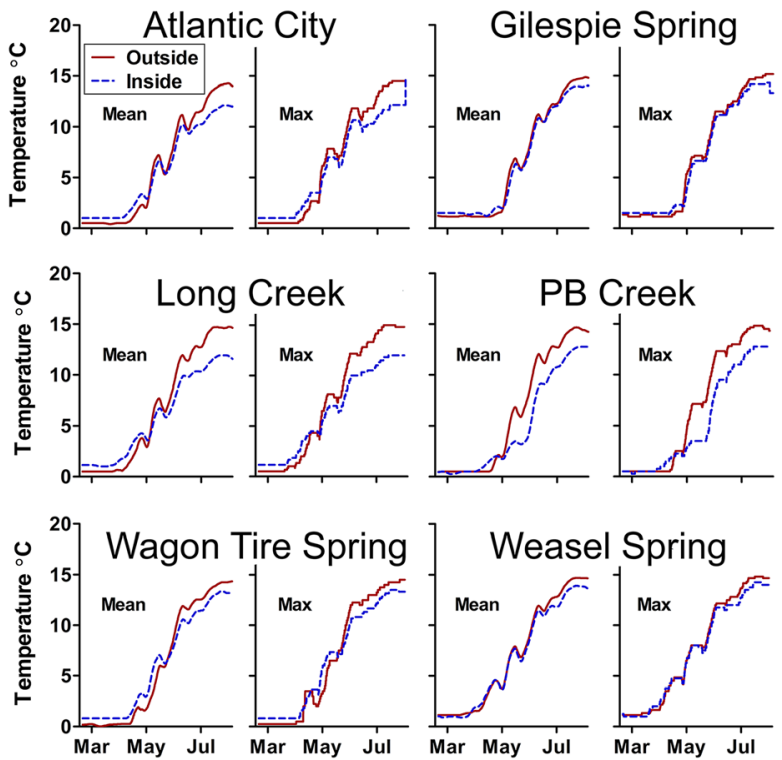

Figure 3. Seven-day rolling mean and max temperature for the $40-\mathrm{cm}$ depth by site, averaged across plots $(N=3)$ inside (ungrazed/blue) or outside (grazed/red) grazing exclosures. 


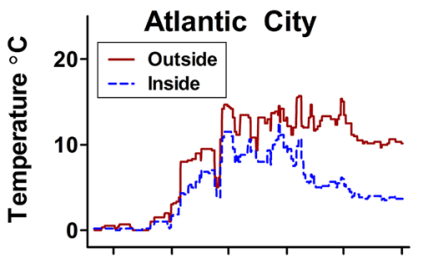

Gilespie Creek
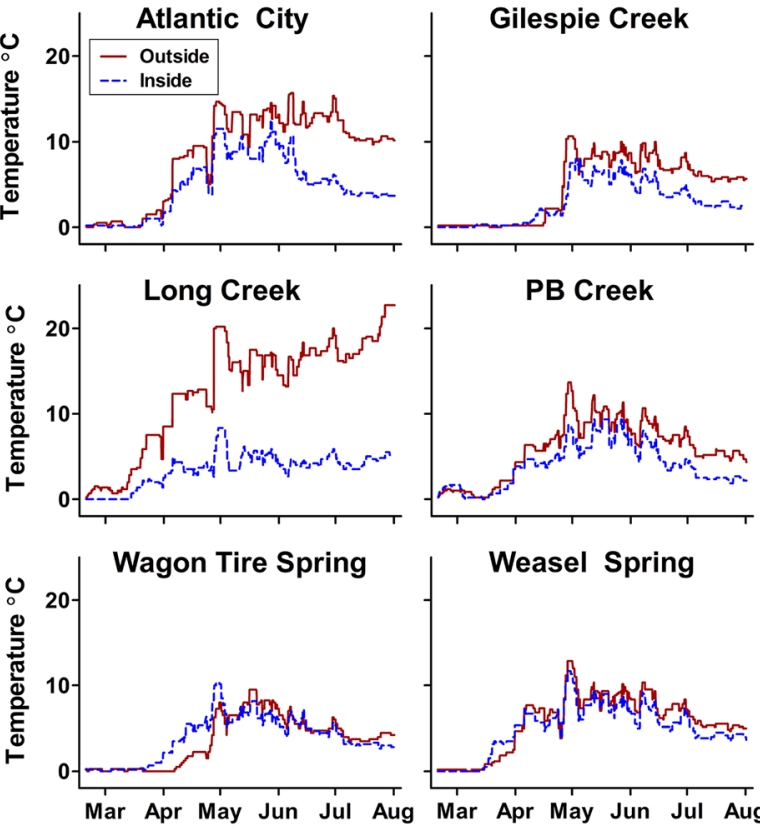

PB Creek

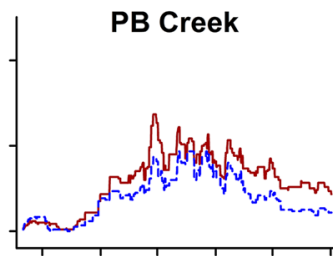

Weasel Spring

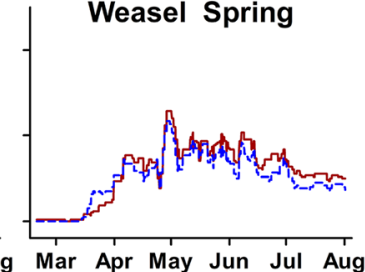

Figure 4. Seven-day rolling temperature range for the 3$\mathrm{cm}$ depth by site, averaged across plots $(N=3)$ inside (ungrazed/blue) or outside (grazed/red) grazing exclosures.


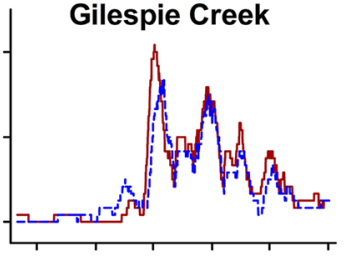

PB Creek

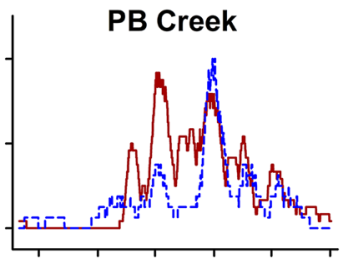

Weasel Spring

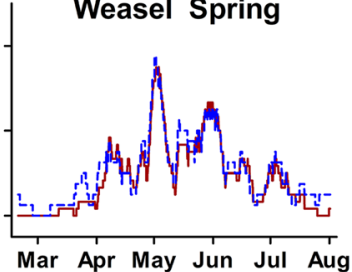

Figure 5. Seven-day rolling temperature range for the 40 -cm depth by site, averaged across plots $(N=3)$ inside (ungrazed/blue) or outside (grazed/red) grazing exclosures.

depth varied inside and outside the exclosures; they did not-the rate of decline for both was stable.
The mean number of days between first and final soil thaw (thaw interval) was shorter inside the exclosure for 22 of 24 paired comparisons $(6$ sites $\times 4$ depths); that is, inside thaw started later but happened faster much like the 2016 versus 2017 thaw dates and rates reported above-and did so for the same longer-warmer-days-of-later-spring reason). Thaw interval averaged 3 days shorter inside the exclosure at all depths, and 7 days shorter at 3-cm depth where daily and weekly temperature variations have the most direct impact on soil temperature. As noted above, thaw rates did have a significant year effect. Although thaw rates did vary significantly between the two years, they were consistent across years and depth, warming


Figure 6. Maximum mean soil temperatures $(\max T)$ by depth for each site. Vertical bars indicate minimum-tomaximum values, not standard error. Fitted maxT outside exclosures (grazed/red) was higher than inside (ungrazed/blue) at all depths and at all sites. Soil temperatures outside exclosures are warmer on average, with mean grazing effect $1.225{ }^{\circ} \mathrm{C}$ and $95 \%$ Confidence Interval $1.168-2.283{ }^{\circ} \mathrm{C}$. Because $\max T$ is estimated from fitted sine waves and each individual estimate has its own variance, observed means are weighted means using weights equal to inverse variances. Vertical bars extend from the smallest to the largest estimates and may be strongly asymmetric about the observed mean because weights significantly vary. The CI is a $95 \%$ interval for the mean of the six sitespecific constant vertical distances between Out/Grazed (red) and In/Ungrazed (blue). 

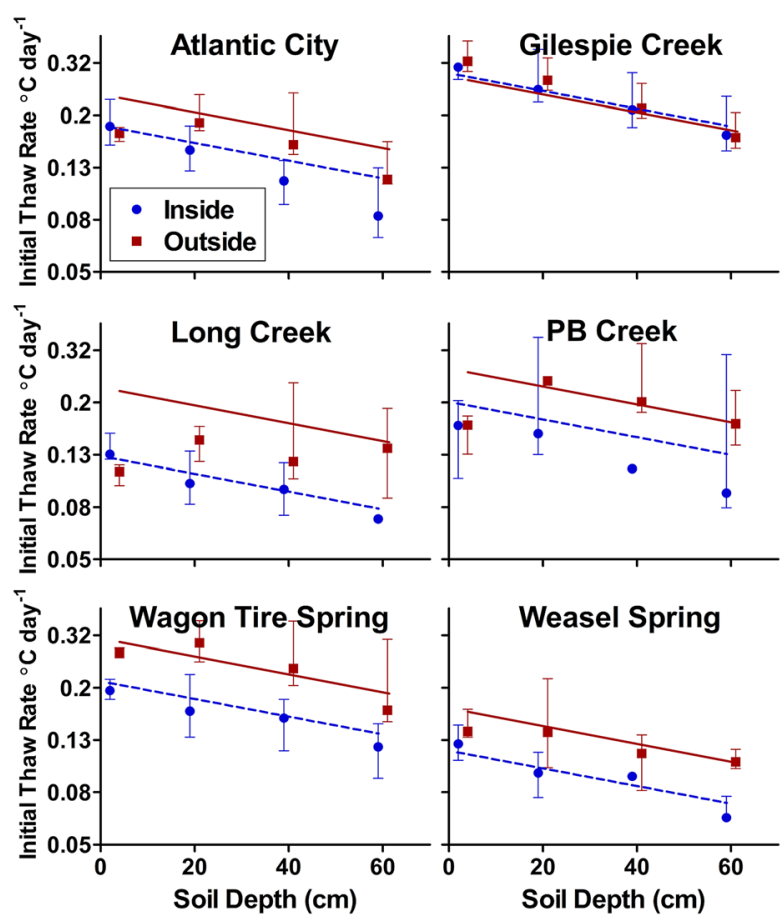

Figure 7. Rate of change at thaw (degrees/day) by depth for each site. Vertical bars indicate minimum-tomaximum values. Fitted rate outside exclosures (grazed/red) was faster than inside (ungrazed/blue) at all depths, at five of six sites. At the sixth, fitted rates were almost identical. Rates outside exclosures across the soil depth profile are $10 \%$ faster on average, with mean grazing effect $0.04{ }^{\circ} \mathrm{C}$ per day and $95 \%$ confidence Interval $0.0402-0.0404{ }^{\circ} \mathrm{C}$ per day. Because thaw rate is estimated from fitted sine waves and each individual estimate has its own variance, observed means are weighted means using weights equal to inverse variances. Vertical bars extend from the smallest to the largest estimates and may be strongly asymmetric about the observed mean because weights significantly vary. The CI is a $95 \%$ interval for the mean of the six sitespecific constant vertical distances between Out/Grazed (red) and In/Ungrazed (blue).
$6.5 \%, 14 \%, 23.5 \%$, and $33.8 \%$ faster at the $3-, 20-$, 40-, and 60-cm depths, respectively, under grazed, compared to ungrazed sites.

\section{Phytomass}

Quadrats within exclosures protected from grazing had approximately $2 \mathrm{X}$ higher dry weight than those placed just outside the exclosures $(p<0.0001, n=3$, Table 2). While treatment effects were highly significant, the site $\mathrm{x}$ treatment interaction had an observed significance level of only $p=0.03$ (Table 3, AOV), perhaps suggesting that inside/outside differences were not as strong as they might have been if all exclosure fences had been more promptly maintained.

\section{Soil Organic Matter}

SOM concentrations were significantly greater inside the fenced area of the three wetlands sampled (Bonferonni-corrected $\alpha=0.0167$, Table 2). Of the three 2011 SOM sites, only PB has significant amounts of organic soils (peats). That difference appears to make PB data different and highly variable compared to the other two sites, precluding a meaningful statistical analysis of SOM with other variables. Summary SOM statistics:

- mean $=16.38 \%$ SOM, sd $=2.32 ; 6$ data points $(3$ sites $\times 2$ treat) weighted by $n$ /variance

- 4 data points (WS and WT), mean = 15.61, $\mathrm{sd}=2.46$; the surprising similarity of means without PB follows because the proper analysis is weighted, and weights on $\mathrm{PB}$ are relatively small because the PB variances are so large.

- There is no significant correlation between SOM and phytomass $(R=0.41 ; p>0.42)$

Table 3. Phytomass Dry Weight Analysis of Variance Table

\begin{tabular}{lrllcc}
\hline & Df & Sum Sq & Mean Sq & $F$ value & $P$ value \\
\hline Site & 5 & 2.1128 & 0.4226 & 2.9965 & 0.03 \\
Treatment & 1 & 4.0343 & 4.0343 & 28.6089 & 0.001 \\
Site $\times$ Treatment & 5 & 2.1293 & 0.4259 & 3.0199 & 0.03 \\
Residuals & 24 & 3.3844 & 0.141 & \\
& & & & \\
\hline
\end{tabular}


Table 4. Sampling Intensity and Statistical Significance in Four Studies of Wetland Carbon Storage

\begin{tabular}{|c|c|c|c|c|c|}
\hline Study & $\begin{array}{l}\text { Meadows compared in } \\
\text { study Design }\end{array}$ & $\begin{array}{l}\text { Years protected from } \\
\text { Grazing }\end{array}$ & $\begin{array}{l}\text { Samples/ } \\
\text { meadow }\end{array}$ & $\begin{array}{l}\text { SOM } \triangle P- \\
\text { value }\end{array}$ & $\begin{array}{l}\text { SOC } \triangle P- \\
\text { value }\end{array}$ \\
\hline $\begin{array}{l}\text { Kauffman and others } \\
\text { (2004) }\end{array}$ & 3 grazed $\times 3$ protected & $14+$ & 5 & 0.42 & - \\
\hline $\begin{array}{l}\text { Wu and others } \\
(2010)\end{array}$ & 1 grazed, 1 protected ${ }^{1}$ & 9 & 25 & $<0.001$ & $<0.01$ \\
\hline $\begin{array}{l}\text { Norton and others } \\
\text { (2011) }\end{array}$ & $5 \mathrm{PFC} \times 6 \mathrm{FAR} \times 6 \mathrm{NF}^{2}$ & na & 24 & - & 0.05 \\
\hline $\begin{array}{l}\text { Norton and others } \\
(2014)\end{array}$ & 18 & $\mathrm{na}^{3}$ & 1 & - & ns \\
\hline \multicolumn{6}{|c|}{$\begin{array}{l}\text { na not applicable } \\
{ }^{1} \text { This was one large, divided meadow. } \\
{ }^{2} P F C=\text { proper functioning condition, FAR = functioning at risk, NF= not functioning. }\end{array}$} \\
\hline
\end{tabular}

\section{Discussion}

We believe this is the first report on soil-profile temperatures in upper-watershed wetlands (HUC 8-10,180,006; USGS 2014). Johnson and others (1971) measured soil temperatures at 20-cm depths in fescue grasslands at Stavely, Alberta, and found heavily grazed pastures had warmer-and drier—soils than lightly grazed pastures of the same grassland. Likewise, Chandler (1940), van der Wal and others (2001) and Stark and others (2015) have documented warmer soils with grazing. These grassland and tundra findings-including the finding of drier soils with grazing-are supported by a more recent careful work on Mongolian grasslands by Yan and others (2018).

Grazing affects more than the vegetative cover. Domestic grazing on wetlands produces a rough ("hummocked") soil surface due to the formation of many large erosion pedestals (Booth and others 2015). This micro-topography exposes more surface, thus absorbing more solar rays, and having more surface area exposed to warmer air, than a smooth surface (Matthias and others 2000). The soil warming we documented for grazed wetlands is consistent with earlier reports showing the importance of standing vegetation-including standing dead and other organic litter-in keeping soils cool (Schuman and others 1980; Fahnestock and others 2000; Yan and others 2018). Hogg and Lieffers (1991) reported soil thaw under unmowed stands of Calamagrostis canadensis (Michx.) Nutt, in northern Alberta, Canada, was up to a month later relative soil in mowed stands. Our results show that this effect on the soil extends down to at least a 60$\mathrm{cm}$ depth which is consistent with Yan and others
(2018) who report an influence to the $100-\mathrm{cm}$ depth.

It is not sufficient to say the grazing effect extends to the 60 or $100-\mathrm{cm}$ depth. We show the percent increase in thaw rate under grazed versus ungrazed wetlands is amplified at depth-at that part of the profile most important to water storage-so that the thaw rate at $60 \mathrm{~cm}$ was more than three times faster under grazed, than under ungrazed wetlands. This is water that, in the ungrazed situation, is more insulated from the temperatures of a warming earth than are mountain snowfields, as was demonstrated at PB Creek, inside, $60 \mathrm{~cm}$ depth.

That SOM would be significantly higher inside the grazing exclosures was expected, but we were surprised at the potential accumulation rate under low or no grazing. For example, Wagon Tire Spring accumulated $45 \%$ more SOM in just seven years inside the exclosure while outside, grazing removed approximately half the standing phytomass (Table 2). However, the accumulation of $>50 \%$ SOM can take decades, as we see in PB Creek after almost 60 years of light grazing.

Quantifying SOM and/or soil organic carbon (SOC) seems to require a high sample density. Kauffman and others (2004) sampled wet meadows, grazed or protected for 14 or more years, and found significant differences between grazing treatments for soil bulk density, pore space, and total below ground plant mass (live and dead roots and rhizomes) but they did not detect a difference in SOM concentration (Table 4). Similarly, Norton and others (2014) did not find a significant relationship between wet meadow SOC concentration and grazing intensity. Yet, Wu and others (2010) report greater amounts of SOM, SOC, and soil 
microbial carbon in high-elevation wet meadows after nine years of protection from grazing as compared to unfenced sites of the same large meadow. If one uses the surface roughness index (SRI; Booth and others 2015) as an indicator of proper functioning condition (PFC), then the findings of Norton and others (2011) suggest land with the lowest SRI (that is, inside the exclosures) will have the greatest amount of SOC. Soils be-

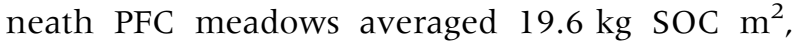
compared to $16.1 \mathrm{~kg}$ SOC $\mathrm{m}^{2}$ beneath functioningat-risk meadows and $11.1 \mathrm{~kg}$ SOC $\mathrm{m}^{2}$ beneath nonfunctioning meadows (Norton and others 2011). Our 2011 SOM survey is consistent with the last two cited reports in having a relatively high sampling intensity, and a finding of significant differences. Taken together, these studies suggest that SOM and SOC are highly variable and likely require high sample density to detect treatment differences (Table 4). We question whether standardized monitoring procedures that collect low sample numbers, such as the National Wetland Condition Assessment (NWCA) which collects only six samples per site (USEPA 2016), can arrive at statistically sound SOM/SOC results. This is not just a problem for the NWCA. Many researchers are likely to follow NWCA methods in project planning. Will those studies have sufficient statistical power to detect real differences in SOM or SOC?

Given (1) the reports of $\mathrm{Wu}$ and others (2010), and Norton and others (2011), (2) that we harvested twice the plant material inside exclosures versus outside, (3) that all exclosures have been fenced more than 10 years (Table 1), (4) our finding of significantly greater SOM inside versus outside for the three sites surveyed in 2011 (Table 2), and (5) our finding of significant inside/outside temperature differences for all sites, we therefore infer inside/outside SOM differences for all study sites.

We believe that soil warming and drying effects can have more bearing on overall riparian $\mathrm{C}$ storage than on the concentration and stocks of organic matter in the wettest positions. Surface SOM content is likely to be less affected by grazing at wetland centers-that is, the wettest positions, which livestock tend to avoid-than at the edges of riparian wetlands. Grazing which removes plant residues at wetland edges may be causing stringer meadows to become narrower and less extensive. Historic aerial photographs examined by Booth and others (2015) and Cox and others (2016) show the effects of the long-term exclosures on the edges of the riparian wetlands, suggesting that long-term season-long grazing is likely the cause of narrowed riparian wetlands. The drying and warming effects of vegetation removal and soil compaction may have caused considerable subsidence of the SOMrich soils but might have had more effect on the overall volume of SOM than its concentration.

What do our findings mean for land managers and downstream water users? Cool soils conserve water by reducing plant evapotranspiration; by slowing the oxidation of water-storing organic matter (Parton and others 1993); and under some conditions, by slowing melting of subsurface ice layers (Clayton 1848; Delano 1854; Booth and Likins, this paper). Organic-rich soils are especially effective for acquiring (by infiltration) and storing water. Organic matter increases the water holding capacity of soil by 3 to more than $25 \%$ depending on soil characteristics and the formation of peat layers (Hudson 1994; Biglow and others 2004; Nusier 2004). Lawrence and Slater (2008) note: (1) organic matter significantly alters a soil's thermal and hydraulic properties, (2) organic-rich soils have greater porosity than low-SOM mineral soils, resulting in greater hydraulic conductivity, a wetter soil column, and weak suction; and (3) reduced summer warming in organic-rich soils results from early season resistance to heat absorption (likely due to water content and the insulating effect of the organic material). Our data support these explanations: The meadow with the greatest 2011 difference in SOM between grazed and ungrazed (PB Creek; Table 2), had the greatest soil temperature delta between grazed and ungrazed $(40-\mathrm{cm}$ depth; April-June; see Figures 5 and 7), and remained partially frozen 20 days longer than any other meadow (thawing at the $60-\mathrm{cm}$ depth on May 31). We suspect the inside/outside rollingmean temperature similarity at PB Creek, $3-\mathrm{cm}$ depth (Figure 2), reflects forage removal from the recent heavier grazing inside, along with reduced grazing outside, the pasture in 2015-2017; but that the inside/outside difference at 40-cm (Figure 3), is due to long term ( $\sim 60$ years) limited inside grazing that resulted in SOM accumulation and conservation versus season-long grazing and limited SOM at depth, outside.

Published data document SOM losses with grazing disturbance (Wu and others 2010) and warming (Parton and others 1993; Wang and others 2018), resulting in soils less capable of storing liquid water. To gauge the ecological significance of our findings, consider that in wetland soils, there's about a $20 \%$ increase in SOM decomposition rate for every degree $C$ increase in temperature (op. cit.). Kauffman and others (2004) estimate undisturbed wet meadows typical of their study 


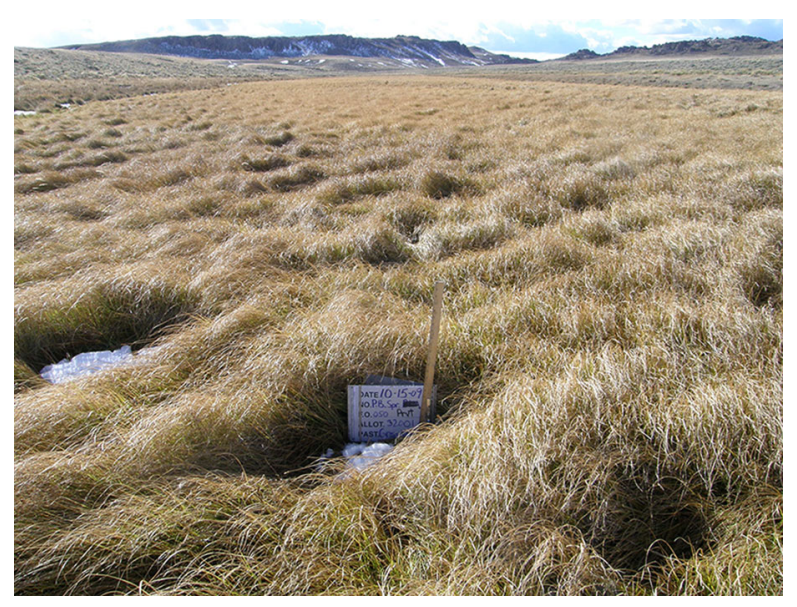

Figure 8. Photograph taken 15 October 2009 looking upstream (west) on PB Creek wetland inside the private pasture. This kind of annual post-grazing-season ground cover contributes to low erosion, high soil organic matter accumulation and maintenance, cooler soils, and to water conservation and storage (photo: J. C. Likins; Booth and others 2015).

area contain at saturation $121,000 \mathrm{~L} \mathrm{ha}^{-1}$ more water than similar grazed meadows. Cumulative impacts of even minor SOM loss and resulting reduction in water holding capacity along thousands of miles of riparian corridors in the western U.S. can, and has, led to significant changes in downstream river flow dynamics, including higher peak flows during floods. Organic matter accumulation in wetlands is also important carbon sequestration and a critical ecological service given rising atmospheric $\mathrm{CO}^{2}$ concentrations (Norton and others 2011, 2014).

We are at a point where many of the predicted effects of climate change are now happening (IPCC 2021). The world's demand for water is rising while many supplies are dwindling (Maddocks and others 2015). That includes Lakes Mead and Powell on the US Colorado River where, because of record-high temperatures and years of drought, the Lakes are at one third of their capacity and predicted to shrink further. For the Colorado and other important rivers of the world, meaningful reductions in grazing headwater riparian systems have the potential to increase water supplies by holding water where it is less subject to evaporation. Evaporation losses from low-elevation lakes, like Lake Mead where evaporative loss estimates range from about 600,000 acre-feet to as much as 875,000 acre-feet annually (Brean 2019), represent water lost when it is rapidly flushed through degraded riparian systems to low-elevation storage. With water shortages becoming more acute, more land managers and administrators should be weighing the economic benefits of grazing wetlands against the costs of compromised ecological services of water and carbon storage.

\section{Conclusions}

Grazing results in warming wetland soils. This is attributed to the loss of shading and insulating vegetation, and to organic litter disturbance, SOM erosion, SOM decomposition, and increasing wetland surface roughness. That SOM corresponded with soil temperature and, as is indicated in the reviewed literature, with soil-water-storage capacity-shows how much soil organic matter, matters. Our findings, and the supporting literature, are reason for land managers to consider spring soilprofile temperatures and SOM as critical ripariancondition indicators. The interaction of SOM with grazing, soil water holding capacity, and soil temperature is an area for further investigation, but current accumulated evidence indicates there is a high cost for grazing headwater riparian areas-a cost largely borne by those downstream in terms of flooding and water scarcity, and by society with respect to reduced carbon storage.

For mountain-watered lands around the world, management for cooler soils will optimize retention of water on the landscape; an especially important consideration where municipalities and other downstream water users are seeking long-term increases in water yield and less flooding (that is, slower runoff). The cooler-soil objective can be achieved by limiting grazing such that riparian lands go into the dormant season with full stands of vigorous vegetation and with no bare ground, rough surface ("hummocks"), or livestock trails (Figure 8).

\section{ACKNOWLEDGEMENTS}

Our research was partly funded by the US Department of the Interior, Bureau of Land Management, and partly through volunteer work of Booth and Likins. The USDA-ARS funded the 2011 analysis of SOM. The University of Wyoming, Department of Ecosystem Science and Management, funded open access publication costs.

\section{Declarations}

Conflict of interest The authors declare that they have no conflict of interest. 


\section{OPEN ACCESS}

This article is licensed under a Creative Commons Attribution 4.0 International License, which permits use, sharing, adaptation, distribution and reproduction in any medium or format, as long as you give appropriate credit to the original author(s) and the source, provide a link to the Creative Commons license, and indicate if changes were made. The images or other third party material in this article are included in the article's Creative Commons license, unless indicated otherwise in a credit line to the material. If material is not included in the article's Creative Commons license and your intended use is not permitted by statutory regulation or exceeds the permitted use, you will need to obtain permission directly from the copyright holder. To view a copy of this license, visit http://creativecommons.org/licenses/by/4.0/.

\section{REFERENCES}

Abaurrea J, Asin J, Cebrian AC, Garcia-Vera MA. 2011. Trend analysis of water quality series based on regression models with correlated errors. J Hydrol 400:341-52.

Aho K, Derryberry D, Peterson T. 2014. Model selection for ecologists: the worldviews of AIC and BIC. Ecology 95:63136. https://doi.org/10.1890/13-1452.1.

Batchelor JL, Ripple WJ, Wilson TM, Painter LE. 2015. Restoration of riparian areas following the removal of cattle in the Northwestern Great Basin. Environ Manag 55:930-42.

Berkamp G, McCartney M, Dugan P, McNeely J, Acreman M. 2000. Dams, ecosystem functions and environmental restoration. Themat Rev II 1:1-187.

Beschta RL, Donahue DL, SellaSala DA, Rhodes JJ, Karr JR, O'Brien MH, Fleischner TL, Williams CD. 2012. Adapting to climate change on western public lands: addressing the ecological effects of domestic, wild, and feral ungulates. Environ Manag. https://doi.org/10.1007/s00267-012-9964-9.

Bezanson CE, Hughes LE. 1989. A Riparian Zone - one story. Rangelands 11:56-7.

Bigelow CA, Bowman DC, Casse DK. 2004. Physical properties of three sand size classes amended with inorganic materials or sphagnum peat moss for putting green rootzones. Crop Sci 44:900-07.

Boeleter DH. 1964. Water storage characteristics of several peats in situ. Soil Sci Soc Am Proc. 28:433-35.

Booth DT, Cox SE, Simonds G, Sant E. 2012. Willow cover as a recovery indicator under a conservation grazing plan. Ecol Indic 18:512-19.

Booth DT, Cox SE, Likins JC. 2015. Fenceline contrasts: grazing increases wetland surface roughness. Wetl Ecol Manag 23:183-94.

Brean H. 2019. Researchers study true scale of evaporation at Lakes Mead, Powell. Boulder City Rev. https://bouldercityre view.com/news/researchers-study-true-scale-of-evaporation-atlakes-mead-powell-51822/. Accessed August 2021.

Chandler RF Jr. 1940. The influence of grazing upon certain soil and climatic conditions in farm woodlands. J Am Soc Agron $32: 216-30$.
Cheesbrough K, Edmunds J, Tootle G, et al. 2009. Estimated Wind River Range (Wyoming, USA) glacier melt water contributions to agriculture. Remote Sens 1:818-28. https://doi. org/10.3390/rs1040818.

Clayton W. 1848. The Latter-Day Saints' Emigrants' guide. Republican steam power press-Chambers \& Knapp, St Louis (reprinted by The Patrice Press c1983).

Cosgrove WJ, Loucks DP. 2015. Water management: current and future challenges and research directions. Water Resour Res 51:4823-839. https://doi.org/10.1002/2014WR016869.

Cox SE, Booth DT, Likins JC. 2016. Headcut erosion in Wyoming's Sweetwater Subbasin. Environ Manag 57:450-62.

Delano, A. 1854. Life on the plains and among the diggings. Miller, Orton \& Mulligan, Auburn, N.Y. (reprinted by University of Nebraska Press, c2005).

Elmore W, Beschta RL. 1987. Riparian areas: perceptions in management. Rangelands 9:260-65.

Fahnestock JT, Povirk KL, Welker JM. 2000. Ecological significance of litter redistribution by wind and snow in Arctic landscapes. Ecography 23(623):631.

Farinotti D, Longuevergne L, Moholdt G, Duethmann D, Molg T, Bolch T, Vorogushyn S, Guntner A. 2015. Substantial glacier mass loss in the Tien Shan over the past 50 years. Nat Geosci. https://doi.org/10.1038/NGEO2513.

Gonzalez MA, Smith SJ. 2020. Riparian area management: proper functioning condition assessment for lentic areas. 3rd ed. Technical Reference 1737-16. U.S. Department of the Interior, Bureau of Land Management. Denver, CO.

Hogan DM, Jordan TE, Walbridge MR. 2004. Phosphorus retention and soil organic carbon in restored and natural freshwater wetlands. Wetlands 24:573-85.

Hogg EH, Lieffers VJ. 1991. The impact of Calamagrostis canadensis on soil thermal regimes after logging in Northern Alberta. Can J Forest Res 21:387-94.

Howat IM, Eddy A. 2011. Multi-decadal retreat of Greenland's marine-terminating glaciers. J Glaciology 57:389-96. https://d oi.org/10.3189/002214311796905631.

Hudson BD. 1994. Soil organic matter and available water capacity. J Soil Water Conserv 49:189-94.

Hunt, ER. 2006. Photograph: airborne view of Wyoming winter snow collected in low-lying draws and riparian areas. Rangeland Ecol Manag. 59 (1): Front Cover.

IPCC (Intergovernmental Panel on Climate Change). 2021. Sixth assessment report, headline statements from the summary for policy makers. (9 August, subject to final copy editing). http s://www.ipcc.ch/report/ar6/wg 1/downloads/report/IPCC_AR6_ WGI_Headline_Statements.pdf. Accessed August 2021.

Johnston A, Dormaar JF, Smoliak S. 1971. Long-term grazing effects on Fescue grassland soils. J Range Manag 24:185-88.

Juliussen H, Christiansen HH, Strand GS, et al. 2010. NORPERM, the Norwegian permafrost database - a TSP NORWAY IPY legacy. Earth Syst Sci Data 2:235-46.

Kasten MJ. 2018. Grazing influence on wetland extent and soil organic carbon storage in the National Trails Management Corridor of Central Wyoming (MS Thesis) Laramie, WY: University of Wyoming. ProQuest 10930917, ProQuest LLC, Ann Arbor, MI, pp 48106 - 1346.

Kauffman JB, Thorpe AS, Brookshire ENJ. 2004. Livestock exclusion and belowground ecosystem responses in riparian meadows of eastern Oregon. Ecol Appl 14:1671-679.

Lawrence DM, Slater AG. 2008. Incorporating organic soil into a global climate model. Clim Dynam 30:145-60. 
Maddocks A, Young SR, Reig P. 2015. Ranking the world's most water-stressed countries in 2040. World Resources Institute. h ttps://www.wri.org/insights/ranking-worlds-most-water-stres sed-countries-2040. Accessed August 2021.

Marzeion B, Cogley JG, Richter K, Parkes D. 2014. Attribution of global glacier mass loss to anthropogenic and natural causes. Science 345:919-21. https://doi.org/10.1126/science.125470 2.

Matthias AD, Fimbres A, Sano EE, et al. 2000. Surface roughness effects on soil albedo. Soil Sci Soc Am J 64:1035-041.

McQueen CB, Andrus RE. 2007. Sphagnaceae. In: Flora of North America North of Mexico. New York and Oxford. Vol. 27:45. (Available online at www.efloras.org/florataxon.aspx?flora_i d=1\&taxon_id=10838, accessed 11 June 2021).

Mitsch WJ, Gosselink JG. 2000. Wetlands, 3rd edn. New York, NY, USA: Van Nostrand Reinhold.

Moomaw WR, Chmura GL, Davies GT, et al. 2018. Wetlands in a changing climate: science, policy and management. Wetlands 38:183-05.

Nagle GN, Clifton CF. 2003. Channel changes over 12 years on grazed and ungrazed reaches of Wickiup Creek in Eastern Oregon. Phys Geogr 24:77-95.

Nayak A, Marks D, Chandler DG, Seyfried M. 2010. Long-term snow, climate, and streamflow trends at the Reynolds creek experimental watershed, Owyhee Mountains, Idaho, United States. Water Resour Res. https://doi.org/10.1029/2008W R007525.

Nelson DW, Sommers LE. 1996. Total carbon, organic carbon, and organic matter. Chapter 34 in methods of soil analysis. Part 3. Chemical methods. Soil science society of America book series no 5. SSSA, Segoe Rd., Madison, WI 53711, USA.

Norton JB, Jungst LJ, Norton U, et al. 2011. Soil carbon and nitrogen storage in upper montane riparian meadows. Ecosystems 14:1217-231.

Norton JB, Olsen HR, Jungst LJ, et al. 2014. Soil carbon and nitrogen storage in alluvial wet meadows of the Southern Sierra Nevada Mountains, USA. J Soils Sediments 14:34-43.

Nusier OK. 2004. Influence of peatmoss on hydraulic properties and strength of compacted soils. Can J Soil Sci 84:115-23.

Odion DC, Dudley TL, D’Antonio CM. 1990. Cattle grazing in southeastern Sierra meadows: ecosystem change and prospects for recovery. In: Hall CA, Doyle-Jones V, Eds. Plant Biology of Eastern California, White mountain research station: University of California, Los Angeles, CA, USA. pp 27792.

Parton WJ, Scurlock JMO, Ojima DS, et al. 1993. Observations and modeling of biomass and soil organic matter dynamics for the grassland biome worldwide. Global Biogeochem Cy 7:785-809.

Pickering CM, Green K. 2009. Vascular plant distribution in relation to topography, soils, and micro-climate at five GLORIA sites in the Snowy Mountains, Australia. Aust J Bot 57:189-99.
Scherrer D, Körner C. 2011. Topographically controlled thermalhabitat differentiation buffers alpine plant diversity against climate warming. J Biogeogr 38:406-16.

Schuman GE, Taylor EM, Rauzi F, et al. 1980. Standing stubble versus crimed straw mulch for establishing grass on mined lands. J. Soil Water Conserv 35:25-27.

Shumway RH, Azari AS, Johnson P. 1989. Estimating Mean Concentrations under Transformation for Environmental Data with Detection Limits. Technometrics 31:347-56. https://doi. org/10.1080/00401706.1989.10488557.

Soil Survey Staff. 2021. Web soil survey. Natural resources conservation service, United States Department of Agriculture. Available online at the following link: http://websoilsu rvey.sc.egov.usda.gov/. Accessed January 7, 2021.

Stark S, Mannisto MK, Ganzert L, Tiirola M, Haggblom MM. 2015. Grazing intensity in subarctic tundra affects the temperature adaptation of soil microbial communities. Soil Biol Biochem 84:147-57.

Swanson S, Franzen D, Manning M. 1987. Rodero Creek: rising water on the high desert. J Soil Water Conserv 42:405-07.

Thompson D, Tootle GA, Kerr G, and others 2011. Glacier variability in the Wind River Range, Wyoming, USA. ASCE $J$ Hydrol Eng https://doi.org/10.1061/(ASCE)HE.1943-5584.000 0384.

USGS [United States Geological Survey] (2014a) National hydrography dataset. http://viewer.nationalmap.gov/viewer/ nhd.html?p=nhd Accessed l July 2021.

USEPA (U.S. Environmental Protection Agency). 2016. National Wetland Condition Assessment 2016: Field Operations Manual. EPA-843-R-15-007. U.S. Environmental Protection Agency, Washington D.C. (https://www.epa.gov/sites/defaul t/files/2017-08/documents/nwca2016_fom_vl_la_full_0.pdf).

Van der Wal R, van Lieshout SMJ, Loonen MJJE. 2001. Herbivore impact on moss depth, soil temperature. Polar Biol 24:29-32.

Wang Q, Zhao X, Chen L, et al. 2018. Global synthesis of temperature sensitivity of soil organic carbon decomposition: latitudinal patterns and mechanisms. Funct Ecol 33:514-23. h ttps://doi.org/10.1111/1365-2435.13256.

Warren A, Jones A. 2012. Forty-five years of public-private partnership in the Rawlins Field Office. Rangelands 34:41-4.

Williams BK, Brown ED. 2019. Sampling and analysis frameworks for inference in ecology. Methods Ecol Evol 10:1832842.

Wu GL, Liu ZH, Zhang L, Chen JM, Hu TM. 2010. Long-term fencing improved soil properties and soil organic carbon storage in an alpine swamp meadow of western China. Plant Soil 332:331-37.

Yan Y, Ruirui Y, Jiquan C, et al. 2018. Grazing modulates soil temperature and moisture in a Eurasian steppe. Agric For Meteorol 262:157-65. 